\title{
17
}

\section{Covering the Politics of Neurodiversity: And Myself}

\author{
Eric M. Garcia
}

I first learned about neurodiversity in the summer of 2015 as a reporter for National Journal. I was recruited there largely by Ron Fournier, a columnist I befriended when I emailed him as a college student after he wrote a story about his son with Asperger's syndrome. Ron suggested I read a book called Neurotribes: The Legacy of Autism and the Future of Neurodiversity by his friend Steve Silberman [1]. It was the first time I read about the neurodiversity movement.

At around that time, I was writing an essay that mixed reporting with my own personal experiences as an autistic reporter for one of the last print editions of National Journal [2]. Even though I had been diagnosed with what was then Asperger's syndrome when I was kid, I had almost no experience writing about my own experiences or exploring much about the autistic community in D.C. or at large. I knew vaguely what autism was but did not know how my own story fits into the larger context about autism and certainly didn't understand what neurodiversity meant.

E. M. Garcia $(\bowtie)$

Washington, DC, USA 
I hoped it would be a fun, chatty piece about the secret lives of autistic reporters and people who work in politics in a city that values social capital even when autism makes socializing difficult.

But the magazine's editor, Richard Just, asked me why this story should exist. In a mix of frustration and hubris, I said American society focuses too much on "curing" autistic people and not enough on helping autistic people, particularly adults. Richard said he wanted 10,000 words on it.

The essay - a slim 6500 words — set my trajectory today [2]. While I didn't have a clear idea of what the term neurodiversity meant, the piece argued policy should bend toward this radical idea. The notion was society should accept and accommodate people with autism, dyspraxia, ADHD, or other conditions considered an abnormality. Neurodiversity wasn't diminishing the specific challenges of autistic people but rather, the essay argued, like other disability rights movements before it, society should welcome neurodivergent people and give them the tools necessary to live a life of dignity. Through research, interviewing, and reporting, I see that neurodiversity is an argument for civil rights; that instead of the world trying to make us be more "neurotypical," the world should celebrate our atypicality and accommodate accordingly.

As a reporter, when I am ignorant about something, I call people knowledgeable about it. But when it came to reporting about autism, I noticed while many journalists quoted parents of autistic children, professors, nonprofits, or legislators, they often ignored autistic people.

Though they have a gross oversight, I don't blame most journalists. Oftentimes when we are ignorant about a new beat, we type in an assortment of words into Google and hope for the best. With autism, the first results are often groups with little autistic representation like Autism Speaks - which only recently began adding autistic people to leadership positions [3] — professors, and parent leaders. Similarly, because autistic people were seen as a burden, they went unheard while their parents' struggles took center stage. Hence, most autism stories don't feature the people with the most expertise: the people who live with autism on a daily basis.

That matters because those who are most heard get the most attention and in turn, are the ones who shape policy. It is for this reason I made it a point when I wrote my initial story to make sure I interviewed as many autistic people as possible. It was largely through Dylan Matthews, 
a writer at Vox.com, that I was introduced by groups like the Autistic Self Advocacy Network; its leaders Ari Ne'eman and Julia Bascom; as well as other prominent autistic advocates like John Elder Robison, Lydia Brown, Liane Holliday Willey, and Dena Gassner.

I became more well-acquainted with other autistic and neurodiversity advocates like Finn Gardiner, Sara Luterman, Samantha Crane, Morénike Giwa Onaiwu and Sharon daVanport. All of them were essential to understanding permutations of autism and what it meant to celebrate neurodiversity, and in turn they gave me resources fellow reporters didn't have: a cache of autistic people whom I could consult anytime autism popped in the news.

It might sound trite to say something "changed my life" but writing and publishing that essay completely upended my career. Since I began as a college reporter, I had been taught to avoid making yourself the news and to be an objective arbiter of the news. But I remember the day the essay being published and receiving a call from Ron on what would be my last day at National Journal with him in tears simply saying "holy shit" with pride at how moved he was by it.

That same day, I got a call from Sen. Orrin Hatch, then the most senior Republican in the United States Senate who was then chairman of the Senate Finance Committee, saying that he had helped sponsor the Americans with Disabilities Act that passed in 1990 and that if I ever wanted to speak with him about autism, I was welcome to visit his office. I had asked Sen. Hatch questions multiple times in the halls of Capitol Hill and was never any more than a nondescript nameless reporter. But now, I was someone whom he knew on a first-name basis and could pick out.

Similarly, for a week, when I opened Twitter I would see journalists whom I deeply admired write about how my essay would "move you." Some of them were bylines I read regularly in The Washington Post, The New York Times, and people elsewhere, and whom I regularly emulated. A few months after the publication of that essay, I saw a journalist I admired and emulated while I was in college at a gala and he told me the piece was amazing. While I was humbled by him complimenting me, in the back of my mind I remembered when he didn't return my email when I was a lowly intern in Washington asking if we could meet for coffee. 
At first this success gave me a sense of vindication about my decision to write. I could now pitch stories about autism and people would consider me credible because I poured my heart into this piece. It also landed me a book contract that would further burnish my credentials as an "autism expert" journalist.

But in the same respect, while I wanted my piece to shed light on autism, I feared that I was just becoming another "inspirational story" about how I overcame autism. I worried that in my attempt to counter the narrative that autism is a debilitating condition, I somehow inadvertently lifted myself up as above being autistic. I don't think I ever said it to myself but possibly subconsciously, what I decided to do as a journalist was to show that my self-portrait was not the outlier but was in fact common among autistic people and that we were in fact, deserving not of pity but of shared humanity.

What was peculiar about this newfound attention was that the essay was published on my very last day at National Journal as I was leaving to start a new job as a staff writer at Roll Call. To boot, I felt like that was the best way to be an effective voice for autistic people; I didn't want to continue dining out on that essay and be seen as "the autistic reporter." I felt-and continue to believe - the best way that I could assist autistic people was to show I was as good of a reporter as my neurotypical counterparts.

As a result, I made it a point that when I began writing my book, which is still in progress as of February 2019, that I would not just make it into a personal memoir, but rather that I would rather chronicle the lives of other autistic people and show how society often creates more obstacles for autistic people than the actual autism does. Similarly, when I was asked to write a piece for the Washington Post about how parents teach autistic boys about consent in sex and relationships, I chose to flip it on its head and say that it is important to teach autistic people consent because they deserve to have as fulfilling love lives and sex lives_-if they so choose-as neurotypical people [4].

The more I researched and the more I saw how politicians discussed autism, the more I felt that while I did not want to become part of the news and did not want to make myself the story, my own understanding of autism and my connections to the disability community could allow 
me to contextualize autism and bring new voices into the public sphere that would not otherwise have been heard.

Incidentally, one of my first opportunities to bring this perspective to my reporting came within months of me starting my job at Roll Call when Democratic nominee Hillary Clinton announced a comprehensive platform on autism [5].

When Clinton embarked on her second presidential campaign in 2016, she released a comprehensive set of policies that read like a neurodiversity wish list like conducting a nationwide survey of autism prevalence in adults, banning physical and chemical restraints, and creating an Autism Works Initiative [5]. As someone who had just written an essay about this a month ago, much of what I read in her policy platform read like things I had heard advocates dream would happen in our interviews.

Clinton's own maturation on autism was reflective of how the politics of autism changed. In a 2007 speech in Sioux City, Iowa Clinton spoke about being a student at Yale Law School and spending a year at Yale's Child Study Center in the 1970s, when autism was still largely blamed on unloving mothers and told a story about a female friend in Little Rock, Arkansas whose son had autism.

"And I spent time in her home, I spent time with her and her son and my instinct perhaps as a mother was that this could not be the explanation," she said [6].

As a senator, Clinton introduced her own legislation called the Expanding the Promise for Individuals with Autism Act, a bill that never passed but was introduced months before her Sioux City speech [7]. In the Sioux City speech, she talked about helping train educators to handle autistic students and providing proper services for autistic adults, which is still groundbreaking by today's standards.

"With access to the right types of services, including housing, vocational rehabilitation, we can help adults with autism live rich and full lives," she said in the speech [8].

But even with these important steps toward progress, Clinton's speech was still couched in the political zeitgeist about autism at the time. In the sentence before saying there are insufficient services, Clinton said "we don't know how to cure it and we don't even know the best ways to treat it" [8]. 
Similarly, Clinton credited parents when she said, "driven by their love and devotion, mothers and fathers across the country have raised awareness, demanded funding, and opened our eyes to the needs of so many children" [8].

Clinton's longstanding focus dating back to at least her days in law school shows her shift in rhetoric from her first to her second presidential run was not solely for political expediency but which came from listening to autistic people.

Part of this was fueled by the fact that Clinton had the support of autistic self-advocates like Ne'eman, who was on the conference call for reporters, including myself, to announce the roll-out of these policies. He said at the time "the fact it was requested and the fact many of these priorities come directly from the community is extremely significant" [9]. While there were a number of estimable reporters on the line, the fact I am autistic I felt could give me an advantage. While other reporters wrote a simple breakdown of the policies, I was able to call autistic self-advocates, who would be the most affected by these policies and chronicle their varied reactions. Being autistic and having that institutional knowledge gave me a roadmap other reporters didn't necessarily have, without bringing my own narrative into the story. It showed that I knew which perspectives mattered the most with these things.

Furthermore, my understanding of autism allowed me to debunk hoaxes and pseudoscience that arose in the campaign. Then-candidate Donald Trump decried autism as being "an epidemic" during the primary debates and told a dubious anecdote about a friend's child becoming autistic after vaccinations [10]. Similarly, during the campaign, Trump met with Andrew Wakefield, the discredited former doctor responsible for promoting the bunk theories of vaccines-autism causation, and Gary Kompothecras, another major promoter of the anti-vaccine theories [11].

After his election, Trump continued his egregious peddling of vaccine theories by promising Robert Kennedy Jr., a prominent anti-vaccine activist, that he would chair a vaccine safety commission [12].

Thankfully, it appears that Trump has not mentioned the idea frequently and Kennedy told the Guardian that the administration "cut off all communication with people who care about this issue” [13]. 
But despite backing away from vaccines, Trump has continued to peddle harmful narratives. On April 2, 2017, Trump's presidential proclamation for World Autism Day read "My Administration is committed to promoting greater knowledge of [autism spectrum disorders] and encouraging innovation that will lead to new treatments and cures for autism" [14].

Similarly, Trump lit the White House blue, which is emblematic of Autism Speaks, for Autism Awareness Day, an action that was criticized because it sees autism as a problem to be fixed and isn't driven by autistic people themselves [15]. Unlike Clinton's comments, these came after better understanding about autism as a condition and after autistic voices have been heard in the public square.

As an autistic political reporter, this new era where there is a resurgence of anti-vaccine conspiracy theories and autism is still used as an epithet at times, often makes me question my place in the autistic community. I am not and will never claim to be the sole voice for autistic people in political media. My other autistic peers are more than capable and probably better at writing about the topic than I am. Similarly, as someone who is now an editor at The Hill, another congressional trade publication, I feel an obligation not to pick one side. But it can at times feel maddening when I feel like the side of autistic people doesn't even get a chance to say anything, even those of my autistic brethren who can't verbally speak.

I don't really know if I have changed people's hearts and minds about autism. At times I worry that I have an inflated view of myself as the guy who is trying to monopolize "the autism beat" in the Washington press corps. But for the time being, I see so few figures who have the context, the understanding and frankly, who care enough to provide those things to news consumers. How could I, when I speak and regularly interact with autistic people, not want to ensure others get our narrative correct? I hope that by both my presence among my colleagues and peers and by the words I write, I can deliver truths not by protesting or lobbying for rights, but by changing who people regard as worthy to deliver their news and ensuring that autistic people are accurately portrayed and their needs be seen as legitimate. 


\section{References}

1. Silberman, S. (2015). Neurotribes: The legacy of autism and the future of neurodiversity. New York, US: Penguin Books.

2. Garcia, E. (2015, December 4). I'm not broken. The Atlantic. Retrieved from https://www.theatlantic.com.

3. Autism Speaks. (2015, December 15). Autism Speaks welcomes three new board members (Press release). Retrieved March 5, 2018, from https://www. autismspeaks.org/news/news-item/autism-speaks-welcomes-three-newboard-members.

4. Garcia, E. (2017, April 27). Autistic men don't always understand consent. We need to teach them. The Washington Post. Retrieved from https://www. washingtonpost.com.

5. Clinton, H. (2016, January 6). Autism policy. Retrieved March 4, 2018, from https://www.hillaryclinton.com/issues/autism.

6. Clinton, H. (2007, November 24). Remarks at the autism event with Sally Pederson in Sioux City, Lowa (Transcript). Retrieved from https://www.cs. cmu.edu/_ark/CLIP/candidates/clinton_h/2007.11.24.remarks_at_the_ autism_event_with_sally_pederson_in_sioux_city_iowa-overlay.html.

7. Clinton, H. (2007, March 20). Clinton introduced autism bill to promote services for those affected by autism (Press release). Retrieved from https:// www.presidency.ucsb.edu/node/297147.

8. Lorentzen, A. (2007, November 25). Clinton would boost autism funding. The Associated Press. Retrieved from http://www.washingtonpost.com/wpdyn/content/article/2007/11/24/AR2007112400924.html.

9. Garcia, E. (2016, January 6). Autism advocates cautiously optimistic on Clinton proposal. Roll Call. Retrieved from https://www.rollcall.com.

10. Beckwith, R. T. (2015, September 18). Transcript: Read the full text of the second republican debate. Time Magazine. Retrieved from http://time.com.

11. Kopplin, Z. (2016, November 18). Trump met with prominent anti-vaccine activists during campaign. Science. Retrieved from http://www.sciencemag. org.

12. Phillip, A., Sun, L. H., \& Bernstein, L. (2017, January 10). Vaccine skeptic Robert Kennedy Jr. says Trump asked him to lead commission on "vaccine safety." The Washington Post. Retrieved from https://www.washingtonpost. com. 
13. Smith, D. (2018, February 21). Trump appears to abandon vaccine sceptic group denounced by scientists. The Guardian. Retrieved from https://www. theguardian.com.

14. Trump, D. J. (2017, March 31). President Donald J. Trump proclaims April 2, 2017 as World Autism Awareness Day. Retrieved March 5, 2018, from https://www.whitehouse.gov/presidential-actions/president-donald-jtrump-proclaims-april-2-2017-world-autism-awareness-day/.

15. DeJean, A. (2017, April 17). The White House turned blue for "autism awareness." That's actually bad for autistic people. Mother Jones. Retrieved from https://www.motherjones.com.

Open Access This chapter is licensed under the terms of the Creative Commons Attribution 4.0 International License (http://creativecommons.org/licenses/by/ $4.0 /$ ), which permits use, sharing, adaptation, distribution and reproduction in any medium or format, as long as you give appropriate credit to the original author(s) and the source, provide a link to the Creative Commons license and indicate if changes were made.

The images or other third party material in this chapter are included in the chapter's Creative Commons license, unless indicated otherwise in a credit line to the material. If material is not included in the chapter's Creative Commons license and your intended use is not permitted by statutory regulation or exceeds the permitted use, you will need to obtain permission directly from the copyright holder.

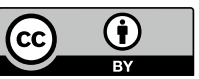

